\title{
Penyusunan Prosedur Operasional Baku Aspek Sistem Manajemen Keselamatan Dan Kesehatan Kerja (Smk3) Di Balai Perawatan Perkeretaapian Ngrombo
}

\author{
Rianto Rili, Julianus Lanang Ose A, Ridwan \\ PTDI-STTD \\ Email : $\underline{\text { rianto.rili@ptdisttd.ac.id }}$
}

\begin{abstract}
Every activity process in a company cannot be separated from everything, the risk of occupational accidents to workers. So, in a company, an Occupational Safety and Health (K3) program is needed to reduce and prevent work accidents. This study aims to determine the safety aspects that have been implemented and to develop Standard Operational Procedures for the K3 aspects at the Balai Perawatan Perkeretaapian Ngrombo. Data collection methods in this study were observation of maintenance activities, survey of safety facilities, and data on the availability of personal protective equipment. Based on the results of the study, it can be seen that the implementation of $\mathrm{K} 3$ at the Balai Perawatan Perkeretaapian is quite good and in accordance with applicable regulations, but there are several safety facilities that are not yet available. Based on the results of the study, suggestions that can be given are that the Balai Perawatan Perkeretaapian should improve the quality of safety facilities and need to apply Standard Operational Procedures for occupational safety and health (K3) aspects so that the safety of all employees is guaranteed. Keyword: Occupational safety and health (K3), Standard Operational Procedures, Balai Perawatan Perkeretaapian Ngrombo.
\end{abstract}

\begin{abstract}
Abstrak
Setiap proses kegiatan dalam suatu perusahaan tidak lepas dari segala hal, risiko kecelakaan kerja hingga pekerja. Maka dalam suatu perusahaan diperlukan program Keselamatan dan Kesehatan Kerja (K3) untuk mengurangi dan mencegah terjadinya kecelakaan kerja. Penelitian ini bertujuan untuk mengetahui aspek keselamatan yang telah diterapkan dan menyusun Prosedur Operasional Standar (SPO) aspek K3 di Balai Perawatan Perkeretaapian Ngrombo. Metode pengumpulan data dalam penelitian ini adalah observasi kegiatan pemeliharaan, survei fasilitas keselamatan, dan data ketersediaan alat pelindung diri. Berdasarkan hasil penelitian dapat diketahui bahwa pelaksanaan K3 di Balai Perawatan Perkeretaapian sudah cukup baik dan sesuai dengan peraturan yang berlaku, namun ada beberapa fasilitas keselamatan yang belum tersedia. Berdasarkan hasil penelitian, saran yang dapat diberikan adalah agar pihak Balai Perawatan Perkeretaapian meningkatkan kualitas fasilitas keselamatan dan perlu menerapkan Standar Operasional Prosedur aspek keselamatan dan kesehatan kerja (K3) agar keselamatan seluruh karyawan terjamin.

Kata kunci: Keselamatan dan Kesehatan Kerja (K3), Standar Operasional Prosedur, Balai Perawatan Perkeretaapian Ngrombo.
\end{abstract}

\section{A. PENDAHULUAN}

Kereta api merupakan salah satu alat transportasi darat antar kota yang diminati oleh seluruh lapisan masyarakat. Dengan semakin banyaknya masyarakat yang menggunakan jasa kereta api sebaiknya diimbangi oleh fasilitas - fasilitas yang memadai, peningkatan kualitas pelayanan yang baik agar masyarakat lebih percaya dan memilih menggunakan jasa 
transportasi kereta api. Perawatan pada sarana merupakan salah satu faktor yang sangat penting untuk menciptakan moda perkeretaapian yang aman, nyaman, cepat, dan tepat waktu.

Balai Perawatan Perkeretaapian merupakan unit kerja di lingkungan Kementerian Perhubungan dibawah naungan Direktorat Jenderal Perkeretaapian yang bertugas merawat dan memelihara sarana perkeretaapian khusus milik negara. Adapun Balai Perawatan Perkeretaapian sendiri terletak di Desa Depo, Kecamatan Toroh, Kabupaten Grobogan, Jawa Tengah.

Balai Perawatan Perkeretaapian memiliki tugas pengendalian kualitas perawatan sarana perkeretaapian milik Negara yang juga dapat merawat sarana dan prasarana perkeretaapian bukan milik negara. Dengan fasilitas sarana dan prasarana yang cukup mumpuni, Balai Perawatan Perkeretaapian dapat melaksanakan perawatan berkala maupun perawatan berat.

Untuk mendukung keselamatan dalam melakukan perawatan tersebut maka dalam sebuah Balai Perawatan Perkeretaapian harus terdapat sistem keselamatan untuk para pegawai. Adapun fasilitas keselamatan tersebut berupa Prosedur Operasional Baku aspek Keselamatan dan Kesehatan Kerja (K3), penanganan jika terjadi kecelakaan kerja, dan panduan jika terjadi sewaktu-waktu terjadi bencana alam di wilayah Balai Perawatan Perkeretaapian.

Keselamatan dan Kesehatan Kerja (K3) merupakan hal yang tidak terpisahkan dalam sistem ketenagakerjaan dan sumber daya manusia. Oleh sebab itu, K3 bukan hanya sekedar kewajiban yang harus diperhatikan oleh para pegawai, akan tetapi kewajiban yang harus dipenuhi oleh sebuah Balai Perawatan Perkeretaapian.

Prosedur Operasional Baku (POB) aspek Keselamatan dan Kesehatan Kerja (K3) memiliki peranan yang sangat penting dalam sebuah perusahan. SOP K3 dapat menjamin hak dari setiap karyawan. Kerugian yang disebabkan oleh kecelakaan sangatlah besar sehingga semua pihak yang terlibat baik pekerja, pimpinan perusahan dan penentu kebijakan harus memahami dan menerapkan program-program tentang K3 sehingga tercipta lingkungan kerja yang aman, nyaman dan sehat. Maka dengan demikian jumlah kecelakaan kerja dapat ditekan dan perusahan tidak akan mengalami suatu kerugian.

Permasalahan yang ada di Balai Perawatan Perkeretaapian yaitu tidak adanya Prosedur Operasional Baku K3. Hal ini menyebabkan kesadaran para pegawai akan keselamatan dalam melakukan perawatan sarana masih sangat kurang.

Selama melakukan penelitian di Balai Perawatan Perkeretaapian Ngrombo, terdapat beberapa insiden kecelakaan kerja ringan. Insiden pertama, sarana lokomotif beserta kereta yang sedang langsir menabrak pintu workshop sehingga menyebabkan pintu rusak cukup berat dan tidak bisa menutup dengan sempurna. Insiden kedua, terdapat teknisi yang terluka pada bagian kaki karena terpleset ketika sedang melakukan perawatan akibat tidak memakai sepatu keselamatan sesuai prosedur.

Berdasarkan permasalahan yang ada, peneliti kemudian bermaksud untuk melakukan penelitian mengenai penyusunan prosedur operasional baku aspek Sistem Manajemen Keselamatan dan Kesehatan Kerja (SMK3) di Balai Perawatan Perkeretaaoian Ngrombo.

\section{B. KAJIAN LITERATUR Prosedur Operasional Baku}


Prosedur Operasional Baku (POB) atau yang biasa disebut SOP adalah dokumen yang berkaitan dengan prosedur yang dilakukan secara kronologis untuk menyelesaikan suatu pekerjaan yang bertujuan untuk memperoleh hasil kerja yang paling efektif dari para pekerja dengan biaya yang serendahrendahnya. POB biasanya terdiri dari manfaat, kapan dibuat atau direvisi, metode penulisan prosedur, serta dilengkapi oleh bagan flowchart di bagian akhir (Laksmi, 2008:52). Tujuan Prosedur Operasional Baku (POB) adalah sebagai berikut (Indah Puji, 2014:30):

a) Untuk menjaga konsistensi tingkat penampilan kinerja atau kondisi tertentu dan kemana petugas dan lingkungan dalam melaksanakan sesuatu tugas atau pekerjaan tertentu.

b) Sebagai acuan dalam pelaksanaan kegiatan tertentu bagi sesama pekerja, dan pengawas.

c) Untuk menghindari kegagalan atau kesalahan.

d) Merupakan parameter untuk menilai mutu pelayanan.

e) Untuk lebih menjamin penggunaan tenaga dan sumber daya secara efisien dan efektif.

f) Untuk menjelaskan alur tugas, wewenang, dan tanggung jawab dari petugas yang terkait.

g) Sebagai dokumen yang akan menjelaskan dan menilai pelaksanaan proses kerja bila terjadi suatu kesalahan atau dugaan human error, sehingga sifatnya melindungi pekerja.

h) Sebagai dokumen yang digunakan untuk pelatihan.

i) Sebagai dokumen sejarah bila telah di buat revisi POB yang baru.

\section{Keselamatan dan Kesehatan Kerja}

Definisi Keselamatan dan Kesehatan Kerja adalah segala kegiatan untuk menjamin dan melindungi keselamatan dan kesehatan tenaga kerja melalui upaya pencegahan kecelakaan kerja dan penyakit akibat kerja (PP 50 Tahun 2012).

Secara filosofi K3 didefinisikan sebagai upaya dan pemikiran untuk menjamin keutuhan dan kesempurnaan baik jasmani maupun rohani diri manusia pada umumnya dari tenaga kerja pada khususnya beserta hasil karyanya dalam rangka menuju masyarakat yang adil, makmur dan sejahtera. Secara keilmuan K3 didefinisikan sebagai ilmu dan penerapannya secara teknis dan teknologis untuk melakukan pencegahan terhadap munculnya kecelakaan kerja dan penyakit akibat kerja dari setiap pekerjaan yang dilakukan. Sedangkan dari sudut ilmu hukum, K3 didefinisikan sebagai salah satu upaya perlindungan agar setiap tenaga kerja dan orang lain memasuki tempat kerja senantiasa dalam keadaan yang sehat dan selamat serta sumber-sumber proses produkasi dapat dijalankan secara aman, efisien dan produktif (Tarwaka, 2014).

Syarat dalam keselamatan dan kesehatan kerja dalam UU No. 1 tahun 1970 tentang Keselamatan Kerja sebagai berikut:

a) Mencegah dan mengurangi kecelakaan

b) Mencegah, mengurangi, dan memadamkan kebakaran

c) Memberi kesempatan atau jalan penyelamatan diri pada waktu kebakaran atau kejadian - kejadian lain yang membahayakan

d) Memberi pertolongan pada kecelakaan

e) Memberi alat pelindung diri pada para pekerja 
f) Mencegah dan mengendalikan timbulnya atau menyebar luasnya suhu, kelembapan, debu, kotoran, asap, uap, gas, aliran udara, cuaca, sinar radiasi, kebisingan dan getaran.

g) Mencegah dan mengendalikan timbulnya penyakit akibat kerja baik fisik

h) maupun psikis, peracunan, infeksi dan penularan

i) Memperoleh penerangan yang cukup dan sesuai

j) Menyelenggarakan suhu dan kelembapan udara yang baik

k) Menyelenggarakan penyegaran udara yang cukup

1) Memelihara kebersihan, kesehatan dan ketertiban

m) Menerapkan ergonomi di tempat kerja

n) Mengamankan dan mengamankan pengangkutan orang dan barang

o) Mengamankan dan memelihara segala jenis bangunan

p) Mengamankan dan memperlancar pekerjaan bongkar muat, perlakuan dan penyimpananan barang

q) Mencegah terkena aliran listrik yang berbahaya

r) Menyesuaikan dan menyempurnakan pengamanan pada pekerjaan yang bahaya kecelakaannya menjadi bertambah tinggi

\section{Alat Perlindungan Diri}

Alat Pelindung Diri atau APD adalah suatu alat yang mempunyai kemampuan untuk melindungi seseorang yang fungsinya mengisolasi sebagian atau seluruh tubuh dari potensi bahaya di tempat kerja. Selanjutnya Peraturan Menteri Tenaga Kerja dan Transmigrasi Republik Indonesia Nomor PER.08/MEN/VII/2010 Tentang Alat Pelindung Diri pada Pasal 2 menjelaskan sebagai berikut:

a) Pengusaha wajib menyediakan APD bagi pekerja/buruh di tempat kerja.

b) APD harus sesuai dengan Standar Nasional Indonesia (SNI) atau standar yang berlaku.

c) APD wajib diberikan oleh pengusaha secara cuma-Cuma

Sedangkan alat pelindung diri menurut Peraturan Menteri Tenaga Kerja dan Transmigrasi Republik Indonesia Nomor PER.08/MEN/VII/2010 Tentang Alat Pelindung Diri, fungsi dan jenis alat pelindung diri yang sering dipakai adalah:

a) Alat pelindung kepala

Fungsi Alat pelindung kepala adalah alat pelindung yang berfungsi untuk melindungi kepala dari benturan, terantuk, kejatuhan atau terpukul benda tajam atau benda keras yang melayang atau meluncur di udara, terpapar oleh radiasi panas, api, percikan bahan-bahan kimia, jasad renik (mikroorganisme) dan suhu yang ekstrim. Jenis-jenis alat pelindung kepala terdiri dari helm pengaman (safety helmet), topi atau tudung kepala, penutup atau pengaman rambut, dan lain-lain.

b) Alat pelindung mata dan muka

Fungsi Alat pelindung mata dan muka adalah alat pelindung yang berfungsi untuk melindungi mata dan muka dari paparan bahan kimia berbahaya, paparan partikelpartikel yang melayang di udara dan di badan air, percikan benda-benda kecil, panas, atau uap panas, radiasi gelombang elektromagnetik, pancaran cahaya, benturan atau pukulan benda keras atau benda tajam. Jenis Jenis alat pelindung mata dan muka terdiri dari kacamata pengaman (spectacles), goggles, tameng muka (face shield), 
masker selam, tameng muka dan kacamata pengaman dalam kesatuan (full face masker).

c) Alat pelindung telinga

Fungsi Alat pelindung telinga adalah alat pelindung yang berfungsi untuk melindungi alat pendengaran terhadap kebisingan atau tekanan. Jenis-jenis alat pelindung telinga terdiri dari sumbat telinga (ear plug) dan penutup telinga (ear muff).

d) Alat pelindung pernapasan beserta perlengkapannya

Fungsi Alat pelindung pernapasan beserta perlengkapannya adalah alat pelindung yang berfungsi untuk melindungi organ pernapasan dengan cara menyalurkan udara bersih dan sehat dan/atau menyaring cemaran bahan kimia, mikroorganisme, partikel yang berupa debu, kabut (aerosol), uap, asap, gas, dan sebagainya. Jenis-jenis alat pelindung pernapasan dan perlengkapannya terdiri dari masker, respirator, katrit, kanister, Re-breather, Airline respirator, Continues Air Supply Machine Air Hose Mask Respirator, tangki selam dan regulator (Self-Contained Underwater Breathing Apparatus /SCUBA), Self-Contained Breathing Apparatus (SCBA), dan emergency breathing apparatus.

e) Alat pelindung tangan

Fungsi Pelindung tangan (sarung tangan) adalah alat pelindung yang berfungsi untuk melindungi tangan dan jari-jari tangan dari pajanan api, suhu panas, suhu dingin, radiasi elektromagnetik, radiasi mengion, arus listrik, bahan kimia, benturan, pukulan dan tergores, terinfeksi zat patogen (virus, bakteri) dan jasad renik. Jenis Jenis pelindung tangan terdiri dari sarung tangan yang terbuat dari logam, kulit, kain kanvas, kain atau kain berpelapis, karet, dan sarung tangan yang tahan bahan kimia.

f) Alat pelindung kaki

Fungsi Alat pelindung kaki berfungsi untuk melindungi kaki dari tertimpa atau berbenturan dengan benda-benda berat, tertusuk benda tajam, terkena cairan panas atau dingin, uap panas, terpajan suhu yang ekstrim, terkena bahan kimia berbahaya dan jasad renik, tergelincir. Jenis Jenis Pelindung kaki berupa sepatu keselamatan pada pekerjaan peleburan, pengecoran logam, industri, kontruksi bangunan, pekerjaan yang berpotensi bahaya peledakan, bahaya listrik, tempat kerja yang basah atau licin, bahan kimia dan jasad renik, dan/atau bahaya binatang dan lain-lain.

g) Pakaian pelindung

Fungsi Pakaian pelindung berfungsi untuk melindungi badan sebagian atau seluruh bagian badan dari bahaya temperatur panas atau dingin yang ekstrim, pajanan api dan benda-benda panas, percikan bahan-bahan kimia, cairan dan logam panas, uap panas, benturan (impact) dengan mesin, peralatan dan bahan, tergores, radiasi, binatang, mikro-organisme patogen dari manusia, binatang, tumbuhan dan lingkungan seperti virus, bakteri dan jamur. Jenis-jenis pakaian pelindung terdiri dari rompi (Vests), celemek (Apron/Coveralls), jaket, dan pakaian pelindung yang menutupi sebagian atau seluruh bagian badan.

\section{Bencana Alam}


Bencana alam merupakan termasuk salah satu faktor yang perlu diperhatikan bagi keselamatan pegawai untuk mengurangi resiko kerugian atau kecelakaan kerja yang ditimbulkan dari bencana alam yang dapat terjadi sewaktu waktu. Salah satu bencana alam yang paling beresiko yaitu angin puting beliung dan kebakaran yang dapat terjadi karena faktor Human Error. Berikut data bencana alam yang terjadi di wilayah Kabupaten Grobogan pada tahun 2017 dan 2018.

Tabel 1. Data Bencana Alam di Kabupaten Grobogan

\begin{tabular}{|c|c|c|c|c|c|}
\hline No & Tahun & Jenis Bencana & Jumlah Kasus & & Keterangan \\
\hline \multirow{2}{*}{1} & \multirow{2}{*}{2017} & Angin Puting Beling & 17 & Kasus & Tertangani \\
\cline { 3 - 6 } & & Kebakaran & 90 & Kasus & Tertangani \\
\hline \multirow{2}{*}{2} & \multirow{2}{*}{2018} & Angin Puting Beling & 11 & Kasus & Tertangani \\
\cline { 3 - 6 } & & Kebakaran & 143 & Kasus & Tertangani \\
\hline
\end{tabular}

Dapat ditarik kesimpulan bahwa bencana angin puting beliung terjadi penurunan dari tahun 2017 ke tahun 2018, namun terjadi peningkatan bencana kebakaran yang sangat tinggi dari tahun 2017 ke tahun 2018 yang meningkat sebanyak 53 kasus. Peningkatan kasus kebakaran di Kabupaten Grobogan tidak terlepas dari kondisi cuaca di Kabupaten Grobogan yang sangat panas pada siang hari.

Oleh sebab itu, perlu adanya kewaspadaan bahwa kebakaran dapat terjadi sewaktuwaktu terlebih lagi wilayah Kabupaten Grobogan memiliki cuaca yang sangat panas pada siang hari sehingga resiko kebakaran sangat tinggi di wilayah Kabupaten Grobogan. Angin puting beliung juga wajib diwaspadai karena angin yang ditimbulkan sangat kencang dan dapat merobohkan sebuah bangunan.

Gempa juga sangat mungkin terjadi di wilayah Kabupaten Grobogan namun sangat jarang terjadi dan biasanya hanya terkena imbas gempa yang berasal dari daerah lain. Gempa di wilayah Kabupaten Grobogan hanya berkisar sekitar 2-4 skala richter. Namun, perlu adanya kewaspadaan terhadap bencana gempa yang tidak dapat diprediksi oleh siapapun.

\section{Penyebab Kecelakaan Kerja}

Terjadinya kecelakaan kerja dapat dilihat dari 3 (tiga) faktor utama yang menjadi penyebabnya menurut Three Main Factor Theory, yaitu:

a) Lingkungan kerja, maksudnya tempat pekerja melakukan pekerjaanya dalam kondisi yang tidak aman atau dalam kondisi membahayakan. Kondisi yang tidak aman ini dapat terjadi karena tidak teraturnya suasana, perlengkapan dan peralatan kerja.

b) Manusia atau karyawan, faktor ini banyak disebabkan oleh beberapa hal:

1) Sifat fisik dan mental manusia yang tidak standar, contohnya: karyawan yang rabun, penerangan kurang, otot lemah, reaksi mental lambat, syaraf yang tidak stabil dan lainya. Bagi yang memiliki sifat dan kondisi seperti ini sering mnjadi penyebab kecelakaan dan gangguan kerja.

2) Pengetahuan dan keterampilan, karena kurangnya pengetahuan maka kurang memperhatikan metode kerja yang aman dan baik, memiliki kebiasaan yang salah, dan kurang pengalaman.

3) Sikap, karyawan memiliki sikap kurang minat dan kurang perhatian, kurang teliti, malas dan sombong (mengabaikan peraturan dan petunjuk), tidak peduli 
akan suatu akibat, hubungan yang kurang baik dengan pihak lain, sifat ceroboh dan perbuatan yang berbahaya.

c) Mesin dan alat, jika pada lingkungan kerja menyangkut pengaturan peralatan dan konstruksi bangunan, maka faktor mesin dan alat ini adalah penggunaan mesin-mesin dan perlatan yang tidak memenuhi standar.

Faktor-faktor sebagaimana dikemukakan di atas mempunyai hubungan yang sangat erat sekali dengan sistem kerja, yang bersumber pada kesalahan manusianya. Sehingga faktor manusia yang mengakibatkan kecelakaan tersebut, adalah:

a) Menggunakan peralatan yang tidak aman

b) Menjalankan peralatan kerja yang tidak tahu caranya

c) Menempatkan bahan-bahan yang tidak aman pada kondisi lingkungan yang mengakibatkan perlawanan arus

d) Merusak alat-alat keselamatan kerja sehingga berakibat tidak baik

e) Salah menggunakan alat kerja

f) Karena gangguan orang lain.

\section{METODE}

Penelitian diawali dengan nelakukan identifikasi masalah berupa mencantumkan latar belakang permasalahan, perumusan masalah, tujuan penelitian, serta batasan penelitian. Kemudian langkah selanjutnya adalah mengumpulkan data sekunder yang didapat dari Balai Perawatan Perkeretaapian dan data primer yang didapat dari kegiatan inventarisasi alat keselamatan serta hasil pengamatan di lapangan pada wilayah studi terkait permasalahan yang ada guna mendukung jalannya penelitian. Berikutnya melakukan analisis terhadap data - data yang diperoleh guna menemukan penyelesaian terhadap permasalahan yang ada. Lalu menggunakan aspek - aspek teoritis dalam pemecahan masalah yang berperan untuk mengubah inputmenjadi output.Metode yang digunakan untuk melakukan proses sehingga menghasilkan solusi dari kondisi ideal yang diharapkan. Terakhir menunjukkan hasil dari pemecahan masalah yang berupa kesimpulan dan saran sebagai rekomendasi dari penelitian ini.

\section{PEMBAHASAN}

\section{Analisis Aspek Keselamatan di Balai Perawatan Perkeretaapian}

Keselamatan dan kesehatan kerja (K3) adalah kondisi dan faktor yang mempengaruhi keselamatan dan kesehatan kerja serta orang lain yang berada di tempat kerja. Berdasarkan UU Ketenagakerjaan No. 13 Tahun 2003 dijelaskan, bahwa setiap perusahaan wajib menerapkan sistem manajemen keselamatan dan kesehatan kerja yang terintegrasi dengan sistem manajemen perusahaan.

Pada Balai Perawatan Perkeretaapian terdapat permasalahan yang perlu segera diatasi. Permasalahan tersebut yaitu terjadi beberapa kecelakaan kerja ringan dan belum adanya Standar Operasional Prosedur aspek Keselematan dan Kesehatan Kerja (K3). Masalah ini jelas bertentangan dengan UU Ketenagakerjaan No.13 Tahun 2003. Sehingga perlu penyelesaian masalah yaitu berupa penyusunan Prosedur Operasional Baku aspek Keselamatan dan Kesehatan Kerja (K3). 
Balai Perawatan memiliki fasilitas keselamatan yang sudah cukup baik, berikut data fasilitas pada WorkshopBalai Perawatan Perkeretaapian:

Tabel 2. Survei fasilitas keselamatan

\begin{tabular}{|l|c|c|c|}
\hline \multicolumn{1}{|c|}{ Fasilitas Keselamatan } & Berfungsi & Rusak & Jumlah \\
\hline Helm Keselamatan & 29 & 4 & 33 Buah \\
\hline Sepatu Boots & 20 & - & 20 Pasang \\
\hline Apar Kecil & 8 & - & 8 Buah \\
\hline Apar Besar & 4 & - & 4 Buah \\
\hline CCTV & 11 & 5 & 16 Buah \\
\hline Kotak P3K & 3 & - & 3 Buah \\
\hline Hydrant & \multicolumn{3}{|c|}{ Tidak Ada } \\
\hline Alarm Keadaan Darurat & \multicolumn{3}{|c|}{ Tidak Ada Ada } \\
\hline Fire Detector & \multicolumn{3}{|c|}{ Tidak Ada } \\
\hline Tandu & \multicolumn{3}{|c|}{ Tidak Ada } \\
\hline Titik Kumpul & \multicolumn{3}{|c|}{} \\
\hline
\end{tabular}

Berdasarkan data diatas, diketahui bahwa terdapat beberapa fasilitas keselamatan yang sudah cukup baik namun jumlah ketersediaan helm keselamatan dengan jumlah ketersediaan sepatu boots tidak sesuai. Sehingga banyak teknisi yang menggunakan helm keselamatan tetapi tidak menggunakan sepatu boots karena keterbatasan jumlah sepatu boots. Terdapat beberapa buah helm keselamatan dan CCTV yang rusak sehingga perlu adanya tindakan perbaikan agar fasilitas keselamatan lebih maksimal.

Balai Perawatan Perkeretaapian memiliki jumlah teknisi perawatan berkala sebanyak 12 orang dan 15 orang pejabat fungsional. Teknisi perawatan berat memiliki teknisi sebanyak 11 orang dan 13 orang pejabat fungsional. Adapun data pegawai pada bidang perawatan berkala dan perawatan berat pada Balai Perawatan Perkeretaapian sebagai berikut:

Tabel 3. Data Jumlah Pegawai Perawatan Balai Perawatan Perkeretaapian

\begin{tabular}{|c|c|c|c|c|}
\hline No & Bidang & Teknisi & Kepala Seksi dan Pejabat Fungsional & Jumlah \\
\hline 1 & Perawatan Berkala & 12 & 16 & 28 Orang \\
\hline 2 & Perawatan Berat & 11 & 14 & 25 Orang \\
\hline \multicolumn{2}{|c|}{ Total } & 53 Orang \\
\hline
\end{tabular}

Teknisi merupakan pelaksana langsung kegiatan perawatan pada Balai Perawatan Perkeretaapian. Pejabat fungsional bertugas mengelola database, melakukan pengendalian mutu, dan membuat pelaporan kegiatan perawatan.

Berdasarkan observasi kegiatan perawatan di lapangan dan perbandingan data ketersediaan fasilitas APD dengan data jumlah pegawai Balai Perawatan Perkeretaapian diperoleh hasil analisis sebagai berikut:

a) Helm sebanyak 33 buah dapat memenuhi 23 orang teknisi yang melakukan perawatan secara langsung, namun tidak dapat memenuhi seluruh pegawai perawatan Balai Perawatan Perkeretaapian yang berjumlah 53 orang karena Kepala Seksi dan Pejabat Fungsional wajib memakai helm ketika melakukan pemantau dan pengecekan kegiatan perawatan. Sehingga perlu adanya penambahan helm sebanyak 20 buah.

b) Sepatu boots memiliki kekurangan sebanyak 3 pasang dari 23 orang jumlah teknisi yang melakukan perawatan. Teknisi diwajibkan memakai sepatu boots karena 
pelaksana utama dalam kegiatan perawatan. Pejabat fungsional tidak diwajibkan memakai sepatu boots ketika melakukan pemantauan dan pengecekan kegiatan perawatan.

Berdasarkan hasil survei alat keselamatan, Balai Perawatan Perkeretaapian belum memiliki beberapa fasilitas penunjang keselamatan seperti:

a) Alarm keadaan darurat

b) Fire detector

c) Hydrant

d) Tandu

e) Titik kumpul (assembly point)

Tidak adanya alarm keadaan darurat membuat pemberitahuan kepada teknisi akan suatu hal yang membahayakan menjadi sulit kurang terkoordinir. Ruangan tertutup yang kurang pengawasan menjadi rawan terjadi kebakaran karena tidak adanya fasilitas fire detector. Tidak adanya hydrant membuat penanganan kebakaran sangat minim karena hanya bertumpu pada apar yang jumlahnya terbatas. Tandu dan titik kumpul berfungsi sebagai fasilitas keselamatan di dalam keadaan darurat. Sehingga sangat diperlukan beberapa fasilitas keselamatan diatas untuk menunjang dan mendukung proses penanganan kecelakaan kerja, kebakaran, dan keadaan darurat (bencana alam).

Rambu-rambu K3 yang terdapat di workshop sudah memenuhi dan sesuai dengan ketentuan yang ditetapkan yang meliputi penempatan, jumlah, bentuk, warna serta pemasangan.

Pemeliharaan workshop dilakukan sebulan sekali yaitu dengan melakukan kerja bakti pada tiap-tiap tempat perawatan sarana yang bertujuan untuk membersihkan sisa-sisa oli dan sampah serta mengembalikan fasilitas perawatan yang tidak sesuai pada tempatnya. Pemeliharaan dan pembersihan workshopini sebagai bagian dari upaya mendukung keselamatan pada Balai Perawatan Perkeretaapian.

Sebelum melakukan perawatan, teknisi bersama Kepala Seksi Perawatan Berkala dan Perawatan Berat melaksanakan apel pagi. Tujuan dari kegiatan apel ini adalah untuk mengecek kelengkapan APD yang wajib dipakai oleh teknisi.

Oleh sebab itu, kegiatan pengecekan kelengkapan APD ini sangat penting untuk dilakukan agar seluruh teknisi memakai APD dengan lengkap dan melaksanakan perawatan dengan aman. Kegiatan apel pagi ini juga menjadi bahan observasi dalam pembuatan Prosedur Operasional Baku (POB) aspek Keselamatan dan Kesehatan Kerja (K3) di Balai Perawatan Perkeretaapian Ngrombo.

Workshop Balai Perawatan Perkeretaapian memiliki ruangan untuk melakukan pengawasan kegiatan perawatan. Ruang pengawasan kegiatan perawatan ini terdapat pada area indoorpada workshopBalai Perawatan Perkeretaapian. Ruangan ini dipakai untuk mengawasi jalannya kegiatan perawatan.

Kekurangan pada ruangan ini yaitu jika pada jalur 1 dan jalur 2 digunakan untuk stabling sarana maka pandangan pada ruangan ini terbatas akibat tertutup oleh badan kereta yang sedang stabling. Terlihat pada gambar diatas terdapat sarana yang sedang stabling di jalur 1, sehingga pandangan pengawas pada ruangan ini terbatas.

Sehingga jalur 1 dan jalur 2 sebaiknya tidak digunakan untuk stabling sarana. Jalur 3 dan jalur 4 dapat digunakan sebagai pengganti jalur stabling sarana. Jalur 5, 6, 7, dan 8 juga dapat digunakan sebagai jalur stabling sarana namun jalur tersebut berada pada area outdoor. 
Ruangan ini memiliki 2 buah komputer yang dapat mengendalikan CCTV untuk memantau kegiatan perawatan. CCTV ini berfungsi sebagai alat bantu dalam pemantauan kegiatan perawatan dan berfungsi untuk merekam kejadian penting ketika terjadi kecelakaan kerja yang dapat dijadikan barang bukti dalam proses penyelidikan. CCTV pada workshop Balai Perawatan Perkeretaapian berjumlah 16 unit.

Perbaikan pada fasilitas CCTVjuga perlu dilakukan, karena terdapat 5 buah CCTV yang rusak dan tidak aktif. Perbaikan CCTVdiharapkan agar pengawasan terhadap kegiatan perawatan dapat lebih maksimal.

\section{Analisis Prosedur Operasional Baku}

Prosedur Operasional Baku aspek Sistem Manajemen Keselamatan dan Kesehatan Kerja (SMK3) ini disusun berdasarkan pengamatan langsung di lapangan dan observasi kegiatan perawatan serta menimbang prosedur yang diperoleh dari Keputusan Direksi PT. KAI Tentang Standar Operasional Prosedur Penanganan Kondisi Darurat di Wilayah Stasiun, Depo, Balai Yasa, dan Dalam Perjalanan Kereta Api. Penyusunan POB ini bertujuan agar seluruh pegawai terjamin keselamatan nya dalam melakukan perawatan.

Selama melakukan penelitian, terdapat 4 pihak pelaksana yang berperan langsung dalam keselamatan kegiatan perawatan. Adapun 4 pihak pelaksana dalam POB ini berdasarkan tupoksinya masing-masing yaitu:

a) Teknisi

1) Bertugas melakukan perawatan secara langsung dengan mematuhi POB K3 yang telah diterapkan.

2) Wajib memakai APD lengkap dan sesuai standar selama melakukan perawatan c. Meminta izin terlebih dahulu kepada pengawas tempat perawatan jika ingin melakukan langsir sarana.

3) Melaporkan kepada pengawas tempat perawatan jika terjadi kecelakaan kerja atau peristiwa kebakaran.

4) Ikut melakukan evakuasi terhadap korban kecelakaan kerja, kebakaran, atau bencana alam.

b) Kepala Seksi Perawatan Bekala dan Perawatan Berat

1) Melakukan pengecekan kelengkapan APD para teknisi sebelum melakukan perawatan dalam kegiatan apel pagi.

2) Menerima laporan atas terjadinya kecelakaan kerja, kebakaran, atau bencana alam

3) Menerima laporan atas kerusakan fasilitas atau sarana yang ditimbulkan.

4) Bertanggungjawab atas evakuasi lanjutan sampai dengan tahap pemulihan dan perbaikan pada fasilitas atau sarana yang mengalami kerusakan.

c) Penanggung-jawab Pengelolaan Tempat \& Fasilitas Perawatan

1) Bertugas membuka seluruh pintu jalur perawatan dan memastikan jalur perawatan steril dari benda apapun sebelum teknisi melakukan perawatan.

2) Mendata dan melakukan pencatatan atas kerusakan fasilitas sarana akibat kecelakaan kerja, kebakaran, atau bencana alam serta perkiraan kerugian yang ditimbulkan.

d) Petugas Pada Ruang Pengawas Tempat Perawatan

1) Melakukan pemantau selama kegiatan perawatan berlangsung. 
2) Melakukan evakuasi terhadap korban kecelakaan kerja, kebakaran, atau bencana alam.

3) Membuat laporan kepada Kepala Seksi Perawatan Berkala atau Perawatan Berat atas terjadinya kecelakaan kerja, kebakaran, atau bencana alam.

Dalam penyusunan POB K3 ini memerlukan beberapa fasilitas keselamatan untuk menunjang penerapannya di lapangan yaitu:

a) Alat Pelindung Diri

Alat pelindung yang diperlukan yaitu helm safety, sepatu boots, pakaian kerja, dan sarung tangan.

b) Alat pemadam kebakaran

Terdiri dari apar berukuran kecil dan apar berukuran besar.

c) Kotak P3K

Berfungsi untuk penanganan pertolongan pertama pada korban jiwa.

d) CCTV

Berfungsi sebagai alat bantu pemantau kegiatan perawatan.

e) Loker

Berfungsi untuk tempat penyimpanan alat pelindung diri bagi teknisi.

f) Tandu (belum ada)

Berfungsi untukalat bantu evakuasi korban kecelakaan kerja, kebakaran, maupun bencana alam

g) Hydrant (belum ada)

Sebagai alat bantu pemadam kebakaran jika apar berukuran kecil maupun apar berukuran besar tidak mampu memadamkan api.

h) Pendeteksi kebakaran (belum ada)

Berfungsi sebagai pendeteksi kebakaran pada tempat-tempat yang tidak terjangkau pengawasan dan tempat rawan terjadi kebakaran.

i) Alam keadaan darurat (belum ada)

Sebagai tanda bahwa terjadi bencana alam atau keadaan darurat agar teknisi segera menghentikan perawatan dan melakukan evakuasi diri masing-masing untuk berpindah ke tempat yang lebih aman dari runtuhan atau goncangan.

j) Titik kumpul (belum ada)

Sebagai titik kumpul jika terjadi keadaan darurat dan proses evakuasi korban.

Dengan kekurangan fasilitas keselamatan yang belum ada, diharapkan untuk Balai Perawatan Perkeretaapian agar melengkapi fasilitas keselamatan guna menunjang POB K3 ini agar lebih maksimal dalam penerapannya di lapangan.

Prosedur Operasional Baku yang disusun terbagi 4 macam, yaitu sebagai berikut:

a) POB K3 dalam melaksanakan perawatan

b) POB K3 penanganan kecelakaan kerja

c) POB K3 penanganan kebakaran

d) POB K3 penanganan bencana alam

Jenis kegiatan yang diwajibkan menggunakan Prosedur Operasional Baku aspek K3 ini yaitu segala macam perawatan berkala maupun perawatan berat yang dilaksanakan di wilayah Workshop Balai Perawatan Perkeretaapian pada jalur indooratau outdoor.

Selama melakukan observasi dan penelitian, Balai Perawatan Perkeretaapian belum mempunyai tim pendukung dan pengawas dalam hal Keselamatan dan Kesehatan Kerja (K3). 
Seperti contoh pada Dipo Lokomotif milik PT. KAI memiliki tim Safety, Healthy, And Environment (SHE) yang bertugas menyusun POB K3 dan melakukan pengawasan secara langsung di lapangan dalam penerapannya.

Saat ini Balai Perawatan Perkeretaapian hanya bertumpu pada Kepala Seksi Perawatan Berkala dan Kepala Seksi Perawatan Berat sebagai penanggungjawab dalam ketertiban penggunaan APD dan penanggungjawab apabila terjadi kecelakaan kerja.

Sehingga Balai Perawatan Perkeretaapian perlu membentuk tim khusus untuk melakukan pengawasan terhadap ketertiban penggunaan APD dan melakukan pengawasan terhadap jalannya POB K3 di lapangan, karena Kepala Seksi Perawatan Berkala dan Kepala Seksi Perawatan Berat tidak dapat selalu mengawasi penerapan POB K3 di lapangan.

\section{Prosedur Operasional Baku Aspek Keselamatan Dan Kesehatan Kerja (K3) Dalam Melaksanakan Perawatan Pada Workshop Balai Perawatan Perkeretaapian.}

a) Teknisi wajib memakai Alat Pelindung Diri (APD) lengkap sebelum melaksanakan apel pagi. Alat pelindung diri yang wajib dipakai sebagai berikut:

1) Helm

2) Pakaian kerja/wearpack

3) Sepatu safety

4) Jaket keselamatan (jika memakai Pakaian Dinas Harian)

b) Kepala Seksi Perawatan Berkala dan Perawatan Berat memimpin jalannya apel pagi sekaligus mengecek kelengkapan Alat Pelindung Diri (APD) para teknisi yang akan melakukan perawatan.

c) Jika terdapat teknisi yang belum memakai Alat Pelindung Diri (APD), maka teknisi yang bersangkutan wajib melengkapi APD yang belum terpakai dan segera melaporkan pada Kepala Seksi Perawatan Berkala dan Perawatan Berat sebelum apel pagi selesai.

d) Penanggungjawab pengelolaan tempat \& fasilitas perawatan membuka seluruh pintu jalur perawatan indoor dan jendela pada workshop serta memastikan bahwa jalur kereta api steril dari benda apapun agar proses langsir berjalan aman dan lancar.

e) Pengawas tempat perawatan melakukan pengawasan kegiatan perawatan sampai selesai dan melakukan pemantauan melalui CCTV.

f) Teknisi melaksanakan perawatan sesuai dengan POB Perawatan dan mematuhi rambu-rambu K3.

g) Teknisi meminta izin kepada pengawas tempat perawatan jika ingin melakukan langsir sarana.

h) Pengawas tempat perawatan memberi izin tertulis kepada teknisi untuk melakukan langsir sarana dan ikut melakukan pemantauan dari CCTV.

i) Pengawas tempat perawatan memastikan kegiatan perawatan berjalan aman dan tidak terjadi kecelakaan kerja.

j) Pengawas tempat perawatan membuat laporan kecelakaan kerja kemudian penanggungjawab pengelolaan tempat dan fasilitas perawatan melakukan pendataan dan pengecekan terhadap kerusakan fasilitas/sarana serta kerugian yang ditimbulkan dari insiden kecelakaan kerja.

k) Teknisi mengecek kembali sarana dalam kondisi mati sebelum meninggalkan workshop. 
1) Kepala Seksi Perawatan Berkala dan Perawatan Berat menerima laporan kegiatan perawatan dan laporan jika terjadi insiden kecelakaan kerja.

m) Teknisi mencuci APD terlebih dahulu yang telah dipakai jika diperlukan, lalu mengembalikan dan menyimpan APD kembali ke loker.

\section{Prosedur Operasional Baku Penanganan Kecelakaan Kerja Pada Workshop Balai Perawatan Perkeretaapian.}

Kecelakaan kerja yang termasuk dalam Prosedur Operasional Baku ini dapat dikategorikan sebagai berikut:

a) Kecelakaan kerja yang menyebabkan terdapat korban luka ringan maupun luka berat.

b) Kecelakaan kerja yang menyebabkan kerusakan pada sarana dan prasarana sehingga perlu adanya perbaikan.

Adapun Prosedur Operasional Baku (POB) penanganan kecelakaan kerja pada WorkshopBalai Perawatan Perkeretaapian sebagai berikut:

a) Teknisi yang melihat peristiwa kecelakaan kerja atau yang selamat segera melaporkan kepada pengawas tempat perawatan tentang:

1) Letak kejadian kecelakaan kerja.

2) Kondisi korban jiwa (perkiraan sementara).

b) Seluruh kegiatan perawatan dihentikan untuk sementara waktu.

c) Pengawas tempat perawatan bersama teknisi yang selamat melakukan evakuasi terhadap teknisi yang terluka.

d) Pengawas tempat perawatan bersama teknisi yang selamat memberikan pertolongan pertama dengan obat-obatan P3K yang sudah disediakan.

e) Memastikan apakah korban terluka berat atau tidak.

f) Jika korban terluka berat, pengawas tempat perawatan menghubungi ambulance atau rumah sakit terdekat.

g) Teknisi yang terluka tidak boleh melakukan perawatan sampai pemulihan selesai

h) Pengawas tempat perawatan membuat laporan atas peristiwa kecelakaan kerja kepada Kepala Seksi Perawatan Berkala dan Perawatan Berat yang berisi tentang:

1) Waktu dan letak kejadian kecelakaan kerja.

2) Jumlah dan kondisi korban jiwa.

3) Tindakan dan pertolongan yang telah dilakukan.

i) Penanggungjawab pengelolaan tempat \& fasilitas perawatan melakukan pengecekan apakah terdapat kerusakaan sarana/fasilitas yang ditimbulkan atau tidak.

j) Jika terjadi kerusakan sarana atau fasilitas, penanggung jawab pengelolaan tempat \& fasilitas perawatan membuat laporan jumlah kerugian dan kerusakan baik dari segi SDM, fasilitas, atau sarana dari insiden kecelakaan kerja yang terjadi.

k) Kepala Seksi Perawatan Berkala dan Perawatan Berat bertanggungjawab atas evakuasi lanjutan sampai tahap pemulihan korban dan tahap perbaikan pada sarana/fasilitas yang mengalami kerusakan.

Pertolongan pertama yang dapat dilakukan untuk korban yaitu sebagai berikut:

a) Jika korban terjatuh dan mengalami patah kaki, segera bawa korban ke tempat yang aman, lalu hubungi dokter jika dibutuhkan. 
b) Jika terdapat goresan dan luka pada tubuh, segera berikan obat dengan cairan iodineyang tersedia pada kotak P3K atau memperban pada daerah luka untuk menghindari infeksi.

c) Jika keracunan gas kimia, segera bawa korban pergi ketempat terbuka dan dalam posisi aman untuk bernafas, lalu berikan nafas buatan.

d) Jika korban terkena luka bakar ringan, masukkan bagian yang terkena pada air dengan atau campuran es dan air, berikan iodinepada luka bakar lalu perban pada bagian kulit yang terbakar.

e) Bila terkena arus listrik, sebelum melakukan apapun putuskan arus listrik pada panel utama, lalu hubungi dokter untuk penanganan medis.

\section{Prosedur Operasional Baku Keadaan Darurat Pada Workshop Balai Perawatan Perkeretaapian}

a) Kebakaran

1) Teknisi yang melihat peristiwa kebakaran atau yang selamat segera melaporkan kepada pengawas tempat perawatan tentang:

- Letak kebakaran

- Kondisi korban

2) Pengawas tempat perawatan menghentikan seluruh kegiatan perawatan.

3) Seluruh teknisi memindahkan barang-barang yang dapat memicu api semakin membesar.

4) Pengawas tempat perawatan memimpin upaya-upaya pemadam kebakaran menggunakan APAR.

5) Memastikan apakah kebakaran sudah dapat dipadamkan atau tidak.

6) Jika api belum dapat dipadamkan, pengawas tempat perawatan segera menghubungi petugas pemadam kebakaran setempat.

7) Melakukan evakuasi terhadap korban dan memberikan pertolongan pertama dengan obat-obatan P3K yang sudah disediakan.

8) Memastikan apakah korban terkena luka bakar serius atau tidak.

9) Jika terdapat korban dengan luka bakar serius, pengawas tempat perawatan segera menghubungi dokter atau ambulance untuk penanganan medis.

10) Teknisi yang terluka tidak boleh melakukan perawatan sampai pemulihan selesai.

11) Pengawas tempat perawatan membuat laporan atas peristiwa kebakaran kepada Kepala Seksi Perawatan Berkala dan Perawatan Berat yang berisi tentang:

- Waktu dan letak kejadian kebakaran.

- Jumlah dan kondisi korban jiwa.

- Tindakan dan pertolongan yang telah dilakukan.

12) Penanggungjawab pengelolaan tempat \& fasilitas perawatan membuat laporan jumlah kerugian dan kerusakan baik dari segi SDM, fasilitas, atau sarana dari insiden kebakaran yang terjadi.

13) Kepala Seksi Perawatan Berkala dan Perawatan Berat bertanggungjawab atas evakuasi lanjutan sampai tahap pemulihan korban dan tahap perbaikan pada sarana dan parasarana yang mengalami kerusakan.

b) Bencana Alam 
Bencana alam yang termasuk dalam Prosedur Operasional Baku ini dapat dikategorikan sebagai berikut:

1) Peristiwa gempa bumi.

2) Peristiwa angin puting beliung.

Adapun Prosedur Operasional Baku (POB) penanganan bencana alam pada Workshop Balai Perawatan Perkeretaapian sebagai berikut:

1) Jika terjadi bencana alam secara tiba tiba, teknisi wajib menghentikan semua kegiatan perawatan.

2) Seluruh pegawai yang berada di dalam workshop sedapat mungkin untuk mengevakuasi diri masing-masing menuju tempat yang aman dari runtuhan atau goncangan.

3) Setelah bencana alam selesai, pengawas tempat perawatan mengecek kondisi workshop apakah terdapat korban jiwa atau tidak.

4) Jika terdapat korban, segera melakukan evakuasi terhadap korban dan memberikan pertolongan pertama.

5) Memastikan apakah korban terluka berat atau tidak.

6) Jika korban terluka berat, pengawas tempat perawatan menghubungi ambulanceatau rumah sakit terdekat.

7) Teknisi yang selamat melakukan pembersihan terhadap puingpuing reruntuhan dan.

8) Pengawas tempat perawatan membuat laporan atas peristiwa kecelakaan kerja kepada Kepala Seksi Perawatan Berkala dan Perawatan Berat yang berisi tentang:

- Waktu dan letak kejadian kecelakaan kerja.

- Jumlah dan kondisi korban jiwa.

- Tindakan dan pertolongan yang telah dilakukan

9) Penanggungjawab pengelolaan tempat \& fasilitas perawatan melakukan pengecekan apakah terdapat kerusakaan sarana/fasilitas yang ditimbulkan atau tidak.

10) Jika terjadi kerusakan sarana atau fasilitas, penanggung jawab pengelolaan tempat \& fasilitas perawatan membuat laporan jumlah kerugian dan kerusakan baik dari segi SDM, fasilitas, atau sarana dari insiden kecelakaan kerja yang terjadi.

11) Kepala Seksi Perawatan Berkala dan Perawatan Berat bertanggungjawab atas evakuasi lanjutan sampai tahap pemulihan korban dan tahap perbaikan pada sarana/fasilitas yang mengalami kerusakan.

\section{KESIMPULAN}

Berdasarkan hasil analisis dan pembahasan yang telah dilakukan, maka dapat diambil kesimpulan bahwa ketersediaan fasilitas Alat Pelindung Diri (APD) pada Balai Perawatan Perkeretaapian sudah cukup baik namun jumlah sepatu boots masih terdapat kekurangan sebanyak 3 pasang untuk teknisi dan penambahan helm sebanyak 20 buah. Terdapat beberapa fasilitas yang mengalami kerusakan berupa helm sebanyak 4 buah dan CCTVsebanyak 5 buah. Kemudian penyusunan Standar Operasional Baku (POB) aspek Keselamatan dan 
Kesehatan ini disusun berdasarkan standar PM 50 Tahun 2017 tentang Pedoman Penyusunan Peta Proses Bisnis Dan Standar Operasional Prosedur Di Lingkungan Kementerian Perhubungan. Lalu prosedur Operasional Baku (POB) ini disusun dengan mempelajari dan memahami setiap kegiatan perawatan yang ada di Balai Perawatan Perkeretaapian. Perancangan POB usulan merupakan POB aspek K3 dalam melakukan perawatan, penanganan kecelakaan kerja, penanganan kebakaran, dan penanganan keadaan darurat (bencana alam). Berikutnya POB K3 yang telah disusun bertujuan agar kegiatan perawatan pada Balai Perawatan Perkeretaapian lebih aman dan dapat menekan resiko kecelakaan kerja yang ada. Terakhir dalam pelaksaanan POB K3 yang telah disusun memiliki beberapa kendala yaitu belum adanya fasilitas keselamatan yang dapat menunjang dalam penerapannya di lapangan, yaitu sebagai berikut: Hydrant; Pendeteksi kebakaran (fire detector); Alarm sebagai tanda keadaan darurat; Tandu; dan Titik kumpul (assembly point).

\section{REFERENSI}

1. Fuad, Laksmi. 2008. Manajemen Perkantoran Modern. Jakarta: Penerbit Pernaka.

2. Hariyono, Widodo. 2016. Standar Operasional Prosedur (SOP) Aspek Keselamatan Dan Kesehatan Kerja (K3) Di Unit Sarana PT. Kereta Api Indonesia (Persero) Daerah Operasi Daop VI Yogyakarta. Yogyakarta: Teknik Industri Universitas Gadjah Mada.

3. Hartatik, Indah Puji. 2014. Buku Pintar Membuat SOP (Standar Operasional Prosedur).Yogyakarta: Flashbooks.

4. Kementrian Perhubungan. 2017. Peraturan Menteri No. 50 Tahun 2017 Tentang Pedoman Penyusunan Peta Proses Bisnis Dan Standar Operasional Prosedur Di Lingkungan Kementerian Perhubungan. Jakarta: Kementrian Perhubungan Republik Indonesia.

5. Komisi Yudisial. 2014. Standar Operasional Prosedur Keadaan Darurat Sekretaris Jenderal Komisi Yudisial. Jakarta: Komisi Yudisial Republik Indonesia.

6. Laksmitha, Astri. 2019. Evaluasi SOP Keselamatan Kerja Pada PT. CNG Plant Cepu. Surabaya: Fakultas Teknologi Kelautan Institut Teknologi Sepuluh Nopember.

7. Republik Indonesia. 1970. Undang-Undang Republik Indonesia Nomor 1 Tahun 1970 tentang Keselamatan Kerja. Jakarta: Kementerian Ketenagakerjaan Republik Indonesia.

8. Republik Indonesia. 2003. Undang-Undang Republik Indonesia Nomor 13 Tahun 2003 tentang Ketenagakerjaan. Jakarta: Kementerian Ketenagakerjaan Republik Indonesia.

9. Tarwaka. 2014. Keselamatan dan Kesehatan Kerja: Manajemen dan Implementasi K3 di Tempat Kerja. Surakarta: Harapan Press.

10. Tim PKL Balai Perawatan Perkeretaapian. 2021. Laporan Umum Balai Perawatan Perkeretaapian Ngrombo. Bekasi: Politeknik Transportasi Darat Indonesia - STTD.

11. Universitas Diponegoro. 2015. SOP Penanganan Kecelakaan Kerja Di Laboratorium. Semarang: Fakultas Teknik Universitas Diponegoro.

12. Wahyu, Andri. 2017. Penerapan Kesehatan Dan Keselamatan Kerja Di Bagian Daily Check Depo Lokomotif Yogyakarta PT. Kereta Api Indonesia (Persero). Yogyakarta: Fakultas Teknik Universitas Negeri Yogyakarta. 